\title{
Formáli ritstjóra
}

Í maí 2014 var kallað eftir greinum um mál og málfræði í 17. hefti Orðs og tungu (2015), án annarrar afmörkunar en peirrar að í tímaritinu væri lögð sérstök áhersla á orðfræði, p. á m. nafnfræði og íðorðafræði, sem og á orðabókafræði og orðabókagerð. Við undirbúning pessa fyrsta heftis undir minni ritstjórn var pannig vikið frá peirri stefnu að vinna með tiltekið pema fyrir hvert hefti. Lengi vel voru haldin árleg málping í tengslum við útgáfu tímaritsins og réð efni peirra síðan pema næsta heftis. Fyrrverandi ritstjóri brá út af peim sið við undirbúning 16. heftis en kallaði eftir greinum í pað hefti með boðsbréfi. Tilgangurinn var að stækka og breikka höfundahópinn. Ég stefni að sama markmiði.

Tímaritinu bárust allmörg handrit innan tilskilins frests og hér birtast pær greinar sem náðu í mark að sinni.

Enda pótt ekki hafi verið lagt upp með tiltekið pema má að vissu marki greina ákveðinn práð í viðfangsefnum greinanna í pessu hefti par sem fjórar fyrstu greinarnar snerta sérstaklega samband íslensks máls og samfélags við önnur evrópsk tungumál og menningu.

Í tveimur fyrstu greinunum er fjallað um afmarkaða flokka tökuorða sem borist hafa til Íslands úr nálægum menningarheimi, p.e. úr pýsku eða dönsku (grein Veturliða G. Óskarssonar) og úr rómönskum málum (grein Erlu Erlendsdóttur). Orðin með pýskættaða forskeytinu beeru nær horfin úr notkun og sýnir Veturliði m.a. fram á að pau hafi alls ekki verið eins útbreidd á 19. öld og gagnrýni málhreinsunarmanna gæti gefið tilefni til aðætla. Rannsókn Erlu á spilaorðum úr spænsku er fróðleg og sýnir tökuorðaferli við tilteknar aðstæður. Marion Lerner veitir innsýn í hugarheim Fjölnismannsins Tómsar Sæmundssonar sem kynnti sér evrópska samtímamenningu á tveggja ára ferðalagi, að hætti ungra evrópskra yfirstéttarmanna, og leitaðist síðan við að miðla henni til landa sinna með íslensku orðfæri sem stundum náði 
skammt. Í fjórðu greininni, sem Mª Azucena Penas Ibáñez og Erla Erlendsdóttir skrifa, er sýndur greinilegur skyldleiki með föstum orðasamböndum í spænsku annars vegar og íslensku hins vegar sem má rekja til sammannlegra tilfinningalegra og líkamlegra viðbragða við ólíkar aðstæður. Í greininni er byggt á hugmyndum og aðferðum hugrænna fræða. Katrín Axelsdóttir skýrir hvernig á pví stendur að orðið hjalt er í fleirtölu ýmist hjölt(in) eða hjöltu(n) og hún sýnir jafnframt hvernig merking pessa orðs hefur prengst. Einnig í pessari grein er samanburður við nálægar tungur skammt undan par sem Katrín rekur m.a., til samanburðar, merkingarpróun enska orðsins hilt. Pau Jón Friðrik Daðason og Kristín Bjarnadóttir lýsa orðhlutaskiptingartóli sem pau nefna Kvist. Kvistur skiptir samsettum orðum og sýnir stofnhlutatré fyrir pau. Í greininni er byggt jöfnum höndum á pekkingu og aðferðum í orðhlutafræði og í máltækni. Hér má sjá dæmi um góða uppskeru af samstarfi sérfræðinga á ólíkum sviðum. Loks höldum við á vit nafnfræðinnar með Sigurði R. Helgasyni. Markmið greinar hans er að skýra uppruna og merkingu óvenjulegra nafngifta: annars vegar Gullbrá og Gullbrárfoss og hins vegar Menglöð og Menglaðarfoss. Sigurður færir rök fyrir pví að í báðum tilvikum sé vísað til gyðjunnar Freyju.

Stefnt er að pví að hafa ritdóm í hverju hefti tímaritsins, um mikilvæga orðabók eða eitthvert annað viðamikið orðfræðilegt eða málfræðilegt verkefni. Pessu hefti lýkur á einum ritdómi: Baldur Sigurðsson fjallar um 3. útgáfu Íslenskrar samheitaorðabókar í ritstjórn Svavars Sigmundssonar. Svavar ritstýrði einnig fyrri útgáfum samheitabókarinnar eins og kunnugt er.

Eins og sjá má eru nú engar stuttar ritfregnir í tímaritinu og sömuleiðis hefur verið fallið frá pví að fjalla sérstaklega um væntanlegar eða afstaðnar ráðstefnur. Meginástæðan fyrir pessari stefnubreytingu er pað mat að lesendur tímaritsins fylgist nú sjálfir vel með útgáfum og ráðstefnum sem pá varðar og falla undir efnissvið tímaritsins. Vefsíður eru almennt notaðar til að kynna hvað eina af pví tagi. Árlegt prentað tímarit er pví nú orðið ekki ákjósanlegasti miðillinn í pví skyni.

Ég færi fyrrverandi ritstjóra Orðs og tungu, Ástu Svavarsdóttur, pakkir fyrir ýmsa aðstoð og góð ráð við undirbúning fyrsta heftisins undir minni ritstjórn. Einnig pakka ég Bessa Aðalsteinssyni, sem annaðist umbrot tímaritsins og samskipti við kápuhönnuð og prentsmiðju, kærlega fyrir samstarfið. Pá færi ég hinni ráðgefandi ritnefnd tímaritsins bestu pakkir fyrir sinn mikilvæga skerf. Loks pakka ég 
öðrum sem veitt hafa aðstoð, við yfirlestur og fleira, og pá einkum og sér í lagi ritrýnum tímaritsins. Allar greinar í tímaritinu eru ritrýndar af tveimur ónefndum sérfræðingum, auk ritstjóra. Lykilatriði við útgáfu fræðilegs tímarits er að geta reitt sig á slíka ritrýni. Peim verður seint fullpakkað sem leggja á sig vandasama og tímafreka vinnu við yfirlestur og umsagnir um greinarhandrit, án nokkurs endurgjalds. 